\section{Activation of Paludrine in vitro}

Paludrine has recently been introduced into clinical medicine as a drug which is highly active against most species of malaria parasite ; its formula is

$$
\mathrm{Cl} \longrightarrow \mathrm{NH} . \mathrm{C}(=\mathrm{NH}) \mathrm{NH} . \mathrm{C}(=\mathrm{NH}) \mathrm{NH} . \mathrm{CH} .\left(\mathrm{CH}_{3}\right)_{2} \text {. }
$$

Tonkin ${ }^{1}$, in this laboratory, investigated its effect on the exoerythrocytic forms of $P$. gallinaceum grown in tissue culture, and found that it had no action upon the parasites in the highest concentrations $(2-5 \mathrm{mgm}$. per litre) tolerated by the macrophages. Since this concentration is many times greater than that which is believed to be present in the plasma in human therapy (probably about $0.3 \mathrm{mgm}$. per litre) its inactivity was surprising; and the action of paludrine in vitro has been investigated further using $P$. cynomolgi of monkeys, and the exoerythrocytic forms of $P$. gallinaceum grown in tissue culture, as test organisms. $P$. cynomolgi was cultured in vitro at $37^{\circ} \mathrm{C}$. by a modification of Bass and John's technique and, 41 hours later, smears were made and stained with Giemsa. The parasites found were classified according to the number of pieces of chromatin present, and the resulting differential counts are shown in the accompanying table. The figures indicate the percentage of parasites containing 1 , 2-3, 4-5 pieces of chromatin, etc., respectively.

\begin{tabular}{|l|c|c|c|c|c|c|}
\hline & 1 & $2-3$ & $4-5$ & $\begin{array}{c}\text { Greater } \\
\text { than 5 }\end{array}$ & $\begin{array}{c}\text { Degen- } \\
\text { erate }\end{array}$ & $\begin{array}{c}\text { Gameto- } \\
\text { cytes }\end{array}$ \\
\hline Original blood & 90 & 10 & 0 & 0 & 0 & 0 \\
\hline Control $A$ & 0 & 6 & 31 & 49 & 10 & 4 \\
\hline $\begin{array}{c}\text { Paludrine } \\
\text { added to } \\
\text { serum } A \\
\text { 2mgm. per } \\
\text { litre }\end{array}$ & & & & & & \\
1 mgm. per & 7 & 27 & 23 & 26 & 9 & 8 \\
litre & 7 & 25 & 26 & 31 & 4 & 7 \\
\hline Paludrine & & & & & & \\
serum $(B)$ & 54 & 23 & 5 & 5 & 10 & 3 \\
$, ", \quad 1 / 4$ & 28 & 46 & 21 & 2 & 0 & 3 \\
$, ", 1 / 16$ & 24 & 42 & 16 & 2 & 8 & 8 \\
,$" 1 / 64$ & 18 & 42 & 24 & 6 & 2 & 8 \\
\hline
\end{tabular}

Monkey $A$ was the donor which provided the parasites, and the serum for the controls and for dilution of serum $B$, etc. Serum $B$ came from a monkey (weighing $3.4 \mathrm{kgm}$.) which had received two intramuscular injections, each of $50 \mathrm{mgm}$. paludrine acetate, 21 and 5 hours previously. Previous experiments had shown that the serum of this monkey had no injurious effects on malaria parasites obtained from monkey $\boldsymbol{A}$.

The table shows that the parasites were originally present as forms with only one piece of chromatin; most of them were small rings. After 41 hours a large proportion in the control tube $A$ had developed so that 49 per cent now possessed more than five pieces of chromatin (at complete schizogony there are sixteen pieces). Very similar development had occurred in the tubes to which paludrine had been added in relatively high concentration. In the tubes containing serum $B$ from the monkey treated with paludrine, development of the parasite was inhibited to a considerable extent, so that 6 per cent or less of the parasites had reached the stage of more than five pieces of chromatin. (Other degenerative changes, which cannot easily be expressed in quantitative terms, were also present in the parasites of these tubes.) This inhibition was marked even in the tube which contained only 1 part of serum $B$ diluted with 63 parts of $A$.

Similar results have been obtained in tissue cultures of the exoerythrocytic forms of $P$. gallinaceum. Serum from a fowl treated with paludrine possesses an anti. plasmodial action which is absent when paludrine is added directly to the cultures. These findings are in agreement with those of Black ${ }^{2}$, who reported that serum from a patient treated with paludrine arrested the development of trophozoites of $P$. falciparum when cultured in vitro; he did not examine the effect of adding paludrine directly to his cultures. It is concluded that probably paludrine does not itself possess antimalarial action, but that it is converted by the body into something which is active.

National Institute for Medical Research, F. HAWKING London, N.W.3. Feb. 3.

${ }^{1}$ Tonkin, I. M., Brit. J. Pharm., 1, 163 (1946).

${ }^{2}$ Black, R. H., Trans. Roy. Soc. Trop. Med. and Hyg., 40, 163 (1946).

\section{An Estrogenic Substance in Pollen-grains of Date Palm Tree Phœnix dactylifera L., Palmæ}

THe term œstrogen or œstrin is now used to designate the whole group of cestrus-inducing substances irrespective of its constitution or origin.

The natural œestrogenic hormones are of wide occurrence, and although œstrogenic substances have been found in mineral sources yet none of naturally occurring cestrogenic hormones has been detected among them. A surprising discovery was that cstrin occurs in the vegetable kingdom. Butenandt and $\mathrm{Jacobi}^{1}$ succeeded in isolating pure œstrone from a palm kernel extract, and Skarzynski ${ }^{2}$ obtained from female willow flowers a crystallizate of pure œstriol, the hormone hydrate. The substances isolated from the plants produced a typical œstrus response in ovariectomized rats.

We have found an œstrogenic substance in pollengrains of the palm plant. The active part is found in the non-saponified fraction of the oil extracted from the dry pollens. A water-soluble form of this active part was made according to Marrian's method and tested biologically. A batch of eleven ovariectomized rats weighing 140-160 gm. were divided into three groups.

Group 1. Three rats received no supplement and used as negative controls.

Group 2. Three rats injected with pure œestradiol dipropionate and used as positive controls.

Group 3. Five rats injected with the water-soluble form obtained from the palm pollen-grains in four doses over a period of twenty-four hours.

All groups were kept under observation and showed no cycles during a preparatory period of two weeks, after which both groups 2 and 3, which were injected with the active material at the same time, showed simultaneously identical complete cornification of the vaginal smear twenty-four hours after the last injection.

This proved the occurrence of a biologically active cestrogenic substance in the pollen-grains of the palm plant.

A spectroscopic examination of this fraction dissolved in absolute alcohol showed an absorption band in the ultra-violet region near $282 \mathrm{~m} \mu$, as compared with the $280 \mathrm{~m} \mu$ of ostrone. 